Available online on 15.1.2017 at http://ujpr.org
Universal Journal of Pharmaceutical Research
An International Peer Reviewed Journal
Open access to Pharmaceutical research is an open access article distributed under the terms of the Creative Commons Attribution-Non
Commercial Share Alike 4.0 License which permits unrestricted non commercial use,
provided the original work is properly cited
Volume 1, Issue 2, 2016

\title{
FORMULATION AND EVALUATION OF FINASTERIDE SUSTAINED- RELEASE MATRIX TABLETS USING DIFFERENT RATE CONTROLLING POLYMERS
}

Igwe J. Chibueze $₫$, Emenike IV $₫$, Oduola AR@

Department of Pharmaceutical Microbiology and biotechnology, Gombe state University, Nigeria.

\section{ABSTRACT}

Objective: Finasteride is chemically considered a synthetic 4-azasteroid drug used in the treatment of anti-hyperplasia. In matrix system of sustained release drug is dispersed homogenously throughout a polymeric matrix. The aim of the present investigation was to develop oral controlled release matrix tablet formulations of Finasteride with different polymer ratios.

Methods: The granules were evaluated for angle of repose, bulk density and Compressibility index before being punched as tablets. Total 5 varieties o of tablets were compressed using polymers (HPMC, EC, Eudragit RS100) in different ratio. The tablets were subjected to weight variation test, drug content, hardness, friability, and in vitro release studies. Different models for kinetic study were applied like zero order, first order, Higuchi, Hixson Crowell and Korsmeyer to study the release pattern and mechanism.

Results: All the formulations showed uniform thickness. In a weight variation test, the pharmacopoeial limit for percentage deviation for the tablets of more than $250 \mathrm{mg}$ is $\pm 5 \%$. The formulation MT5 showed a comparatively high hardness value of $4.8 \pm 0.22 \mathrm{~kg} / \mathrm{cm} 2$. Matrix tablets of batch MT1 shows maximum release $86.42 \%$ in $10 \mathrm{hrs}$.

Conclusion: Observations of all formulations for physical characterization had shown that, all of them comply with the specifications of official pharmacopoeias and/or standard references. Study concludes that Finasteride can be delivered effectively in the form of matrix tablets.

Keywords: Matrix tablets, sustained release, wet granulation.

Article Info: Received 1 November 2016; Revised 4 December; Accepted 28 December, Available online 15 January 2017

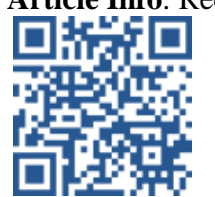

\section{Cite this article-}

Igwe J. Chibueze, Emenike IV, Oduola AR. Formulation and evaluation of Finasteride sustained-release matrix tablets using different rate controlling polymers. Universal Journal of Pharmaceutical Research 2016; 1(2): 15-18. DOI: http://doi.org/10.22270/ujpr.v1i2.R3

Address for Correspondence

Igwe J. Chibueze, Department of Pharmaceutical Microbiology and biotechnology, Gombe state University, Nigeria, E-mail: Igwejames42@yahoo.com

\section{INTRODUCTION}

Sustained release systems drug delivery system achieves slow release of drug over an extended period of time. It provide an immediate dose required for the normal therapeutic response, followed by the gradual release of drug in amounts sufficient to maintain the therapeutic response for a specific extended period of time $^{1}$. Sustained release of drugs in gastrointestinal tract followed by oral administration is not affected by the absorption process and, it provides blood levels that are devoid of the peak and valley effect which are characteristics of the conventional intermittent dosage regimen $^{2}$. Matrix is defined as a well-mixed composite of one or more drugs with gelling agent i.e. hydrophilic polymers. In matrix system of sustained release drug is dispersed homogenously throughout a polymeric matrix $^{3}$. It includes coating and pelletization during manufacturing and rate of drug release from the dosage form is controlled mainly by the type and proportion of polymer used in the preparations. Advantages of matrix tablets are ${ }^{4,5,6,7}$ : easy to fabricate in different shape and size, high level of reproducibility suitable for both non degradable and degradable system, no dose dumping, effective, stable and economical, suitable for drugs having high molecular weight.

Finasteride is chemically considered a synthetic 4azasteroid $\mathrm{drug}^{8}$. It is an enzyme inhibiting agent. It is used in the treatment of anti-hyperplasia and also used as anti-baldness agent. The mechanism of action of Finasteride is based on its preferential inhibition of Type II 5a-reductase by formation of a stable complex with the enzyme. This enzyme converts testosterone to dihydrotestosterone (DHT), which is a more potent androgenic hormone. Inhibition of Type II 5a-reductase blocks the peripheral conversion of testosterone to $\mathrm{DHT}^{9}$. Significant decrease in serum and tissue DHT concentrations, increase in serum testosterone concentrations, and substantial increases in prostatic 
testosterone concentrations. The drug is an effective therapeutic agent in the treatment of benign prostatic hyperplasia. Inhibition of the enzyme 5 alpha-reductase is believed to be the mechanism of action of this $\operatorname{drug}^{10}$. An increase in the level of DHT in the prostate results in prostate hyperplasia and urinary tract obstruction. The drug is practically insoluble in water, with a mean bioavailability of $63 \%$. The oral bioavailability of finasteride is $65 \%$, mean half-life is 4.5-8 $\mathrm{h}^{11}$. In present study matrix type tablets of Finasteride were prepared to improve the bioavailability of it.

\section{MATERIALS AND METHODS}

Finasteride was a gift sample from Fidson healthcare. Eudragit RS-100 was obtained from Neimeth, and HPMC from Zolon healthcare, Nigeria. All other chemicals used were of analytical grade.

\section{Preparation of tablets}

The granules prepared by wet granulation of drug, filler and hydrophilic polymers were compressed into flat faced tablets using by using $\mathrm{KBr}$ press. The diameter of the die was $12 \mathrm{~mm}$ and the batch size prepared for each formulation was of 20 tablets.

Table 1: Composition of matrix type tablets of Finasteride.

\begin{tabular}{lccccc}
\hline \begin{tabular}{l} 
Ingredients \\
\multicolumn{1}{c}{$(\mathbf{m g})$}
\end{tabular} & \multicolumn{5}{c}{ Formulation Code } \\
\cline { 2 - 6 } & MT1 & MT2 & MT3 & MT4 & MT5 \\
\hline Finasteride & 80 & 80 & 80 & 80 & 80 \\
HPMC & 100 & 100 & 100 & 100 & 100 \\
EC & - & 100 & 100 & - & - \\
Eudragit RS 100 & - & - & 100 & 100 & 100 \\
$\begin{array}{l}\text { Ethanol } \\
\text { Magnesium }\end{array}$ & qs & qs & qs & qs & qs \\
$\begin{array}{l}\text { stearate } \\
\begin{array}{l}\text { Dicalcium } \\
\text { phosphate }\end{array}\end{array}$ & 4 & 4 & 4 & 4 & 4 \\
Talc & 90 & 90 & 90 & 90 & 90 \\
\hline
\end{tabular}

\section{Evaluation of Granules}

\section{Angle of repose}

The angle of repose of prepared granules was determined by the funnel method. The accurately weighed granules were taken in a funnel. The granules were allowed to flow through the funnel freely onto the surface $^{12}$. The diameter of the powder cone was measured and angle of repose was calculated using the following equation:

$$
\tan \theta=\frac{\mathrm{h}}{\mathrm{r}}
$$

Where, $\mathrm{h}$ and $\mathrm{r}$ are the height and radius of the powder cone.

\section{Bulk and tapped density}

A quantity of $2 \mathrm{~g}$ of powder from each formula, previously lightly shaken to break any agglomerates formed, was introduced into a $10 \mathrm{ml}$ measuring cylinder. After the initial volume was observed, the cylinder was allowed to fall under its own weight onto a hard surface from the height of $2.5 \mathrm{~cm}$ at 2 second intervals ${ }^{13}$. The tapping was continued until no further change in volume was noted.

\section{Carr's compressibility index}

The Carr's compressibility index was calculated from Bulk density and tapped density of the granules. A quantity of $2 \mathrm{~g}$ of granules from each formulation, filled into a $10 \mathrm{ml}$ of measuring cylinder. Initial bulk volume was measured, and cylinder was allowed to tap from the height of $2.5 \mathrm{~cm}$. The tapped frequency was $25 \pm 2$ per min to measure the tapped volume of the granules. The bulk density and tapped density were calculated by using the bulk volume and tapped volume ${ }^{14}$.

\section{Hausner's ratio}

Hausner ratio $(\mathrm{Hr})$ is an indirect index of ease of powder flow ${ }^{15}$. It is calculated by the ratio of tapped and bulk density.

\section{Drug content}

An accurately weighed amount of powdered Finasteride granules $(100 \mathrm{mg})$ was extracted with water and the solution was filtered through $0.45 \mu$ membrane. The absorbance was measured at $254 \mathrm{~nm}$ after suitable dilution $^{16}$.

\section{Evaluation of tablets}

Thickness and diameter

Thickness and diameter of tablets was determined using Vernier caliper. Five tablets from each batch were used, and average values were calculated ${ }^{17}$.

\section{Weight variation test}

Twenty tablets were selected randomly from each batch were weighed individually.

The tablet passes the test if not more than two tablets fall outside the percentage limit and none of the tablet differs by more than double the percentage limit ${ }^{18}$.

\section{Drug content}

Five tablets were weighed individually and triturated. Powder equivalent to the average weight of the tablet was weighed and drug was extracted in water for 6 hours. The solution was filtered through $0.45 \mu$ membrane ${ }^{19}$. The absorbance was measured at $254 \mathrm{~nm}$ after suitable dilution.

\section{Hardness}

For each formulation, the hardness of 6 tablets were determined using the Monsanto hardness tester. The tablet was held along its oblong axis in between the two jaws of the tester. At this point, reading should be zero $\mathrm{kg} / \mathrm{cm}^{2}$. Then constant force was applied by rotating the knob until the tablet fractured. The value at this point was noted in $\mathrm{kg} / \mathrm{cm}^{2}$. Generally, a minimum of $4 \mathrm{~kg} / \mathrm{cm}^{2}$ hardness is considered acceptable for uncoated tablets ${ }^{20}$.

\section{Friability}

For each formulation, the friability of 6 tablets was determined using the Roche friabilator. This test subjects a number of tablets to the combined effect of shock abrasion by utilizing a plastic chamber which revolves at a speed of $25 \mathrm{rpm}$, dropping the tablets to a distance of 6 inches in each revolution ${ }^{21}$. A sample of pre weighed 6 tablets was placed in Roche friabilator which was then operated for 100 revolutions i.e. 4 minutes. The tablets were then dusted and reweighed. A loss of less than $1 \%$ in weight in generally considered acceptable.

\section{In vitro release studies}

In vitro drug release study for the prepared matrix tablets were conducted for period of 8 hours using a six 
station USP XXVI type II (paddle) apparatus at $37 \pm 0.5^{\circ} \mathrm{C}$ and $50 \mathrm{rpm}$ speed. The dissolution studies were carried out in triplicate for 10 hours in phosphate buffer of pH 6.8 under sink condition. At first half an hour and then every 1 hour interval samples of $5 \mathrm{ml}$ were withdrawn from dissolution medium and replaced with fresh medium to maintain the volume constant. After filtration and appropriate dilution, the sample solution was analyzed at $254 \mathrm{~nm}$ for Finasteride by a UV- spectrophotometer ${ }^{21}$. The amounts of drug present in the samples were calculated with the help of appropriate calibration curve constructed from reference standard.

\section{RESULTS AND DISCUSSION}

The current investigation deals with the optimization of sustained release matrix tablets of Finasteride using different polymers. Polymers used were HPMC, Ethyl cellulose and Eudragit RS100. All the formulations showed uniform thickness. In a weight variation test, the pharmacopoeial limit for percentage deviation for the tablets of more than $250 \mathrm{mg}$ is $\pm 5 \%$. The average percentage deviation of all the tablet formulations was found to be within the above limit, and hence all the formulations passed the test for uniformity of weight as per the official requirements. Satisfactory uniformity in drug content was found among different batches of tablets, and percentage of drug content was more than $96 \%$. The formulation MT5 showed a comparatively high hardness value of $4.8 \pm 0.22 \mathrm{~kg} / \mathrm{cm}^{2}$. This could be due to the presence of more ethylcellulose which is generally responsible for more hardness of the tablet. In the present study the percentage friability for all the formulations was below $1 \%$ indicating that the friability is within the prescribed limits. All the tablet formulations showed acceptable pharmacotechnical properties and complied with the in-house specifications for weight variation, drug content, hardness and friability. The release of drug mainly depends upon the polymer concentration. Matrix tablets of batch MT1 shows maximum release $86.42 \%$ in $10 \mathrm{hrs}$. The quick release was observed in tablets containing ethylcellulose, it may be due to high solubility of EC at $\mathrm{pH}$ 6.8. This polymer characteristic gives to the matrix a quick gel erosion rate and a high erosion degree of the overall system. The in-vitro release data was applied to various kinetic models to predict the drug release kinetic mechanism. Nanoparticles were fitted with various kinetic equations like zero order, first order and Higuchi'smodel, Korsemeyer-peppas and Hixon crowell.

Table 2: Evaluation parameters of granules.

\begin{tabular}{|c|c|c|c|c|c|}
\hline $\begin{array}{c}\text { Formulation } \\
\text { code }\end{array}$ & $\begin{array}{c}\text { Bulk } \\
\text { density }\end{array}$ & $\begin{array}{l}\text { Tapped } \\
\text { density }\end{array}$ & $\begin{array}{l}\text { Carr's } \\
\text { index }\end{array}$ & $\begin{array}{c}\text { Hausner's } \\
\text { ratio }\end{array}$ & $\begin{array}{c}\text { Angle of } \\
\text { repose ( } \theta)\end{array}$ \\
\hline MT1 & 0.304 & 0.358 & 12.5 & 1.77 & $39^{\circ} 6^{\prime}$ \\
\hline MT2 & 0.392 & 0.384 & 13.41 & 0.97 & $38^{\mathrm{O}} 4^{\prime}$ \\
\hline MT3 & 0.341 & 0.427 & 14.52 & 1.25 & $37^{\circ} 9^{\prime}$ \\
\hline MT4 & 0.322 & 0.403 & 15.6 & 1.26 & $37^{\circ} 6^{\prime}$ \\
\hline MT5 & 0.298 & 0.358 & 16.5 & 1.20 & $35^{\mathrm{O}} 2^{\prime}$ \\
\hline
\end{tabular}

Table 3: Evaluation parameters of Finasteride tablets.

\begin{tabular}{cccccc}
\hline $\begin{array}{c}\text { Formulation } \\
\text { code }\end{array}$ & Hardness & Thickness & $\begin{array}{c}\text { \% } \\
\text { Friability }\end{array}$ & $\begin{array}{c}\text { Weight } \\
\text { variation } \\
(\boldsymbol{\%})\end{array}$ & $\begin{array}{c}\text { Drug } \\
\text { content } \\
(\boldsymbol{\%})\end{array}$ \\
\hline MT1 & $4.4 \pm 0.21$ & $2.25 \pm 0.04$ & $0.73 \pm 0.05$ & $2.63 \pm 0.05$ & $96.32 \pm 0.08$ \\
MT2 & $4.5 \pm 0.14$ & $2.37 \pm 0.11$ & $0.71 \pm 0.08$ & $2.84 \pm 0.06$ & $97.53 \pm 0.15$ \\
MT3 & $4.1 \pm 0.09$ & $2.18 \pm 0.06$ & $0.78 \pm 0.09$ & $3.22 \pm 0.11$ & $98.43 \pm 0.16$ \\
MT4 & $4.6 \pm 0.15$ & $2.43 \pm 0.15$ & $0.70 \pm 0.04$ & $3.12 \pm 0.09$ & $99.11 \pm 0.05$ \\
MT5 & $4.8 \pm 0.22$ & $2.32 \pm 0.07$ & $0.81 \pm 0.03$ & $2.93 \pm 0.08$ & $99.65 \pm 0.06$ \\
\hline
\end{tabular}

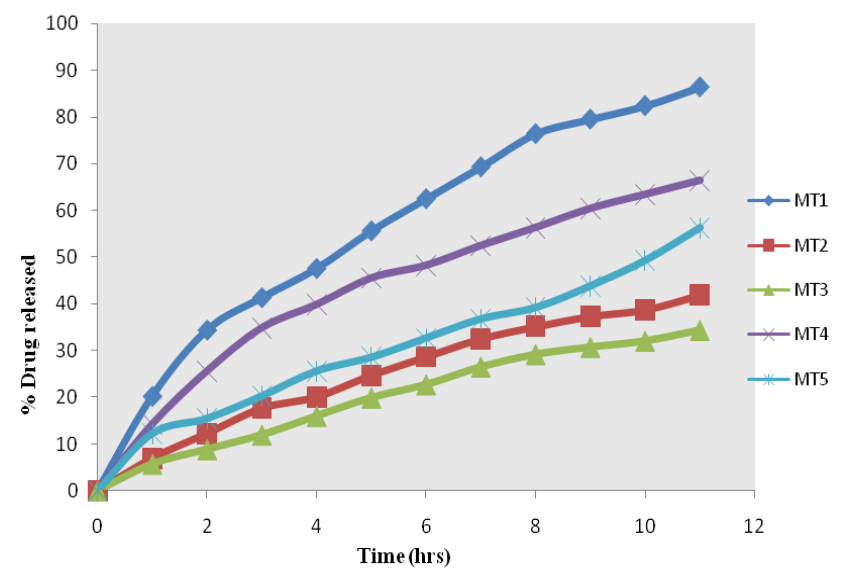

Figure 1: In-vitro drug release profile of Finasteride tablets. 
Table 4: Dissolution profile of Finasteride tablets.

\begin{tabular}{llllll}
\hline $\begin{array}{l}\text { Formulation } \\
\text { code }\end{array}$ & $\begin{array}{l}\text { Zero } \\
\text { order }\end{array}$ & $\begin{array}{l}\text { First } \\
\text { order }\end{array}$ & Higuchi & Korsemeyer-Peppas & $\begin{array}{l}\text { Hixon } \\
\text { Crowell }\end{array}$ \\
\hline MT1 & 0.8350 & 0.9215 & 0.9562 & $0.9892, \mathrm{n}=0.3942$ & 0.9452 \\
\hline MT2 & 0.9108 & 0.9558 & 0.9845 & $0.9926, \mathrm{n}=0.5214$ & 0.9832 \\
\hline MT3 & 0.9217 & 0.9315 & 0.9915 & $0.9946, \mathrm{n}=0.6011$ & 0.9915 \\
\hline MT4 & 0.8864 & 0.9011 & 0.9965 & $0.9921, \mathrm{n}=0.5246$ & 0.9924 \\
\hline MT5 & 0.8075 & 0.9295 & 0.9872 & $0.988847, \mathrm{n}=0.5642$ & 0.9835 \\
\hline
\end{tabular}

\section{CONCLUSION}

The present research work was successful in improving the efficacy of Finasteride oral therapy as the drug release was extended for ten hours thus reducing dosing frequency thereby improving patient compliance. Based on different evaluation parameters formulation of batch MT1 is concluded as an optimum formulation.

\section{AUTHOR'S CONTRIBUTION}

The manuscript was carried out, written, and approved in collaboration with all authors.

\section{ACKNOWLEDGEMENTS}

The authors extend their thanks and appreciation to the Gombe state University, Nigeria to provide necessary facilities for this work.

\section{CONFLICT OF INTEREST}

No conflict of interest was associated with this work.

\section{REFERENCES}

1. Augsburger L, Rekhi GS, Nellore VR. Identification of critical formulation and processing variables for metoprolol tartarate extended release matrix tablets. J Control Rel 1999; 59:327-342.

https://doi.org/10.1016/S0168-3659(99)00004-8

2. Sako K, Nakashima H. Influence of water soluble fillers in hydroxypropylmethyl cellulose matrices on in vitro and in vivo drug release. J Cont Rel 2002; 81:165-172. https://doi.org/10.4103\%2F0975-1483.66793

3. Hilton $\mathrm{AK}$ and Deasy PB. In vitro and in vivo evaluation of an oral sustained release floating dosage form of amoxicillin trihydrate. Int J Pharm 1992; 86:79-88. https://doi.org/10.1016/0378-5173(92)90033-X

4. Fassihi R, Jamzad S. Analysis of macromolecular changes and drug release from hydrophilic matrix systems. Int $\mathbf{J}$ Pharm 2005; 292:75-85.

https://doi.org/10.1016/j.ijpharm.2004.11.011

5. Hogan JE. Hydroxypropyl methylcellulose sustained release technology. Drug Dev Ind Pharm 1989; 15(27): 975-999.https://doi.org/10.1208\%2Fs12249-012-9829-9

6. Ozturk AG, Ozturk SS, Plasson BO. Mechanism of release from pellets coated with an ethyl cellulose-based-film. J Control Rel 2010; 14(3): 203-213. https://doi.org/10.1016/0168-3659(90)90160-U

7. Seng CH, Haesum P, Peggy Khan. Bioadhessive polymers as platforms for oral controlled release drug delivery II. Synthesis and evaluation of some swelling, water-insoluble bioadhessive polymers. J Pharm Sci 1985; 74: 399-405. https://doi.org/10.4314/tjpr.v9i1.52043

8. Yamana K, Labrie F, Luu-The V. Human type $35 \alpha-$ reductase is expressed in peripheral tissues at higher levels than types 1 and 2 and its activity is potently inhibited by finasteride and dutasteride. Hormone Mol Biol Clin Invest 2010; 2 (3): 20-25.https://doi.org/10.1515/hmbci.2010.035

9. Tacklind, J, Fink HA, Macdonald R, Rutks I, Wilt TJ. Finasteride for benign prostatic hyperplasia. The Cochrane database of systematic reviews 2010; (10): 8-15. https://doi.org/10.2147\%2Ftcrm.s6195

10. Belknap SM, Aslam I, et al. Adverse Event Reporting in Clinical Trials of Finasteride for Androgenic Alopecia: A Meta-analysis. JAMA dermatology 2015; 151: 600-6. https://doi.org/10.1001/jamadermatol.2015.36

11. Mella JM, Perret MC, Manzotti M, Catalano HN, Guyatt G. Efficacy and safety of finasteride therapy for androgenetic alopecia: a systematic review. Archives Dermatol 2010; 146 (10): 1141-50

12. Crowley MM. Physiochemical properties and mechanism of drug release from ethylcellulose matrix tablets prepared by direct compression and hot-melt extrusion. Int $\mathbf{J}$ Pharm 2004; 269, 509-522. https://doi.org/10.1016/j.ijpharm.2003.09.037

13. Katzhendler I, Mader K, Friedman M. Structure and hydration properties of HPMC matrices containing naproxen and naproxen sodium. Int J Pharm. 2000; 20, 161179. https://doi.org/10.1016/S0378-5173(00)00360-4

14. Mohammad SI, Reza S, Rahman H. In vitro Release Kinetics Study of Diltiazem Hydrochloride from Wax and Kollidon SR Based Matrix Tablets. Iranian J Pharm 2008; 7 (2): 101-108.

15. Gilbadi M, Feldman S. Establishment of sink conditions in dissolution rate determinations- theoretical considerations and application to nondisintegrating dosge forms. J Pharm Sci 1967; 56: 1238-1242. https://doi.org/10.1002/jps.2600561005

16. Al-saidan SM, Krishnaiah YSR, Patro SS, Satyanarayana V. In-vitro evaluation of guar gum matrix tablets for oral controlled release of water-soluble Diltiazem hydrochloride. AAPS Pharm Sci Tech. 2005; 6(1): E14E21. https://doi.org/10.1208\%2Fpt060105

17. Frick A, Moller H, Wirbitzki E. In vitro/in vivo biopharmaceutical characterization of oral immediate release drug products. Comparison of phenoxy methylpenicillin potassium, glimepiride and levofloxacin. Eur J Pharm Biopharm 1998; 46: 305-11. https://doi.org/10.1016/S0939-6411(98)00041-1

18. Bogner RH. Bioavaliablity and Bioequivalence of extended release oral dosage forms, US pharmacist, 22. 1997; 3-12.

19. Khan GM, Zhu JB. Controlled release coprecipitates of Ibuprofen and Carbopol 934- Preparation, characterization and in vitro release. Sciences 2007; 33: 627-639.

20. Silvina A, Bravo Maria C, Lamas Claudio J. Salomon. Invitro studies of diclofenac sodium controlled-release from biopolymeric hydrophilic matrices. J Pharm Pharmaceutics Sci 2003; 5(3): 213-219.

21. Mote PB, Rawat PK, Singh SK, Zadbuke NS. Formulation and evaluation of sustained release matrix tablets of antiasthmatic agent using various polymers. J Drug Deliv Therap 2013; 3(2): 88-92. https://doi.org/10.1016\%2Fj.jsps.2012.03.006 